\title{
Ventral Striatal Dopamine Release in Response to Smoking a Regular vs a Denicotinized Cigarette
}

\author{
Arthur L Brody*,1,2, Mark A Mandelkern 2,3, Richard E Olmstead², Zoe Allen-Martinez ${ }^{2}$, David Scheibal ${ }^{2}$, \\ Anna L Abrams ${ }^{2}$, Matthew R Costello ${ }^{1,2}$, Judah Farahi ${ }^{2}$, Sanjaya Saxena ${ }^{4}$, John Monterosso' and \\ Edythe D London ${ }^{1,5}$ \\ 'UCLA Department of Psychiatry and Biobehavioral Sciences, Los Angeles, CA, USA; ${ }^{2}$ Greater Los Angeles VA Healthcare System Positron \\ Emission Tomography Center, Los Angeles, CA, USA; ${ }^{3}$ UCI Department of Physics, Irvine, CA, USA; ${ }^{4}$ UCSD Department of Psychiatry, \\ San Diego, CA, USA; ${ }^{5}$ UCLA Department of Molecular and Medical Pharmacology, Los Angeles, CA, USA
}

\begin{abstract}
Prior studies have demonstrated that both nicotine administration and cigarette smoking lead to dopamine (DA) release in the ventral striatum/nucleus accumbens. In tobacco-dependent individuals, smoking denicotinized cigarettes leads to reduced craving, but less pleasure, than smoking regular cigarettes. Using denicotinized cigarettes and ${ }^{~ ' C}$-raclopride positron emission tomography (PET) scanning, we sought to determine if nicotine is necessary for smoking-induced DA release. Sixty-two tobacco-dependent smokers underwent " C-raclopride PET scanning, during which they smoked either a regular or denicotinized cigarette (double-blind). Change in ${ }^{11} \mathrm{C}$-raclopride binding potential (BP) in the ventral striatum from before to after smoking was determined as an indirect measure of DA release. Cigarette craving, anxiety, and mood were monitored during scanning. Smoking a regular cigarette resulted in a significantly greater mean reduction in ventral striatal ${ }^{~ '} \mathrm{C}$-raclopride BP than smoking a denicotinized cigarette. Although both groups had reductions in craving and anxiety with smoking, the regular cigarette group had a greater improvement in mood. For the total group, change in BP correlated inversely with change in mood, indicating that greater smoking-induced DA release was associated with more smoking-related mood improvement. Thus, nicotine delivered through cigarette smoking appears to be important for ventral striatal DA release. Study findings also suggest that mood improvement from smoking is specifically related to ventral striatal DA release.

Neuropsychopharmacology (2009) 34, 282-289; doi:I0.1038/npp.2008.87; published online 18 June 2008
\end{abstract}

Keywords: dopamine; nicotine; tobacco; ventral striatum; positron emission tomography; ${ }^{\prime}$ C-raclopride

\section{INTRODUCTION}

Many research groups have demonstrated that nicotine administration or cigarette smoking results in dopamine (DA) release in the ventral striatum/nucleus accumbens (VST/NAc). In studies of rodents, nicotine-induced DA release in the VST/NAc was shown using microdialysis (Di Chiara and Imperato, 1988; Damsma et al, 1989; Pontieri et al, 1996; Sziraki et al, 2001), whereas nicotine-induced DA release was disrupted by lesioning of dopaminergic neurons prior to nicotine administration (Corrigall et al, 1992). In non-human primates, DA release in response to intravenous nicotine administration has been demonstrated (indirectly) by displacement of ${ }^{11} \mathrm{C}$-raclopride (a ligand that binds to D2/D3 DA receptors) during positron emission tomography (PET) scanning (Dewey et al, 1999; Marenco et al, 2004). Similarly, studies of human smokers have

*Correspondence: Dr AL Brody, UCLA Department of Psychiatry \& Biobehavioral Sciences, 300 UCLA Medical Plaza, Suite 2200, Los Angeles, CA 90095, USA, Tel: + 310268 4778, Fax: + 310206 2802, E-mail: abrody@ucla.edu

Received 6 March 2008; revised 9 May 2008; accepted 10 May 2008 demonstrated DA release in response to cigarette smoking (Brody et al, 2004, 2006; Scott et al, 2007) and nicotine gum administration (Takahashi et al, 2008) using ${ }^{11}$ C-raclopride and PET, though not all studies using these (and similar) methods have shown ${ }^{11} \mathrm{C}$-raclopride displacement (Tsukada et al, 2002; Barrett et al, 2004; Montgomery et al, 2007). Both nicotine administration (in doses comparable to human cigarette smoking) (Cumming et al, 2003; Marenco et al, 2004; Takahashi et al, 2008) and cigarette smoking itself (Brody et al, 2004, 2006; Scott et al, 2007) result in DA release in the range of $5-10 \%$, indicating that nicotine intake is an important factor in DA release from smoking. Significant associations between DA release (as measured by ${ }^{11} \mathrm{C}$-raclopride displacement) and behavioral responses to smoking, such as reduction in craving (Brody et al, 2004, 2006) and enhancement of pleasure (Barrett et al, 2004; Montgomery et al, 2007), have also been demonstrated in human smokers.

In prior research, smoking denicotinized cigarettes has been compared to smoking regular cigarettes, to examine the effect of the presence or absence of nicotine on tobaccorelated symptoms. In tobacco-dependent smokers, smoking denicotinized cigarettes has been found to result in a degree 
of withdrawal relief that is similar to smoking regular cigarettes (Pickworth et al, 1999; Buchhalter et al, 2001; Dallery et al, 2003; Donny et al, 2007); however, denicotinized cigarettes provide less satisfaction (Butschky et al, 1995; Gross et al, 1997), reward (Naqvi and Bechara, 2005; Donny et al, 2007), and anxiety reduction (Pomerleau et al, 1984; Buckley et al, 2007) than regular cigarettes. Denicotinized cigarettes also do not elevate heart rate like regular cigarettes (Butschky et al, 1995; Pickworth et al, 1999; Schuh et al, 2001; Buchhalter et al, 2001), but both cigarette types increase skin conductance responses (Naqvi and Bechara, 2006). Furthermore, a recent study directly demonstrated that the airway sensation from nicotinized cigarette puffs were more rewarding than such sensations from denicotinized cigarette puffs (though both cigarette types produced greater reward than unlit puffs) (Naqvi and Bechara, 2005). Taken together, these studies indicate that sensory factors associated with smoking are important for relief of withdrawal, but that nicotine may be necessary for the rewarding properties of smoking.

Using denicotinized (and regular) cigarettes and ${ }^{11} \mathrm{C}$-raclopride PET scanning, the primary goal of the study presented here was to determine if nicotine is necessary for smoking-induced DA release. Given the extensive scientific literature linking reward/pleasure with DA release (Koob, 1992; Leshner and Koob, 1999) and the aforementioned studies of denicotinized cigarettes indicating less of a rewarding effect from these cigarettes, we hypothesized that smoking a denicotinized cigarette during scanning would result in less DA release than smoking a regular cigarette. Given that prior studies demonstrate associations between DA release and hedonic responses and craving reduction with smoking, and that smoking reduces anxiety in the presence of a stressor (Jarvik et al, 1989) and when a distractor is present (Kassel and Shiffman, 1997), we also sought to examine associations between DA release and change in these symptoms with smoking.

\section{METHODS}

\section{Research Participants}

Two hundred and forty-three potential research participants were screened during a telephone interview, in which medical, psychiatric, and substance abuse histories were obtained without personal identifiers. Qualified participants who wished to participate received a complete description of the study in person and gave written informed consent, using forms approved by the local IRB. Participants were then evaluated further using screening questions from the Structured Clinical Interview for DSM-IV to verify eligibility (First et al, 1995). Inclusion/exclusion criteria were the same as in our previous reports (Brody et al, 2004, 2006), with the central inclusion criteria being DSM-IV nicotine dependence and smoking 10-40 cigarettes per day and exclusion criteria being any history of an Axis I psychiatric or substance abuse/dependence diagnosis other than nicotine dependence, current use of medications or medical conditions that might affect brain function, and pregnancy. Participants were all treatment seeking and were either enrolled in a larger smoking cessation treatment study or offered open-label treatment following study participation.

\section{Experimental Design}

Sixty-two otherwise healthy adult (21-65 years of age) cigarette smokers completed the following study. Participants underwent bolus-plus-continuous-infusion ${ }^{11} \mathrm{C}$-raclopride PET scanning, during which they smoked either a regular or denicotinized cigarette (double-blind). Demographic and other clinical variables were collected at baseline, and symptoms of tobacco withdrawal were monitored during the scanning session. A structural magnetic resonance imaging (MRI) scan was also obtained within 1 week of the PET session.

\section{Demographic and Rating Scale Measures}

Demographic and rating scale measures were obtained immediately prior to PET scanning. Demographic data included age, sex, number of cigarettes per day, number of years smoking, and highest level of education. Rating scale data included the Fagerström Test for Nicotine Dependence (FTND) (Fagerström, 1978; Heatherton et al, 1991), Hamilton Depression (HAM-D) (Hamilton, 1967) and Anxiety (HAM-A) (Hamilton, 1969) rating scales, and the Shiffman-Jarvik Withdrawal Scale (Shiffman and Jarvik, 1976). Exhaled carbon monoxide (CO) levels were also obtained prior to PET scanning using a MicroSmokerlyzer (Bedfont Scientific Ltd, Kent, UK) as an estimate of recent smoking levels.

During the PET session, the Urge to Smoke (UTS) Scale for measuring craving (Jarvik et al, 2000), state anxiety questions from the Spielberger State-Trait Anxiety Index (Spielberger, 1983), and an analog scale for mood rating (from 'sad' to 'happy') (Wild et al, 2001; Bowen et al, 2006; Mitterschiffthaler et al, 2007) were administered immediately before and after smoking.

\section{PET and MRI Scanning}

Positron emission tomography and MRI scanning sessions followed the same general protocol as in our previous reports (Brody et al, 2004, 2006). PET sessions were performed using a bolus plus continuous infusion of ${ }^{11} \mathrm{C}$ raclopride. Participants were instructed to smoke as per their usual habit on the morning of the PET session and to smoke a cigarette immediately prior to testing, which began at noon. Between noon and 1345 hours, participants were interviewed and filled out rating scale questionnaires as described above. At 1345 hours, each participant had a 20gauge intravenous catheter placed and then was positioned on the PET scanning bed (for acquisition of planes parallel to the orbitomeatal line). Scanning began at 1410 hours with a slow bolus injection of $5 \mathrm{mCi}{ }^{11} \mathrm{C}$-raclopride in $20 \mathrm{ml}$ normal saline over a 60 -s period, followed by continuous infusion of the tracer ( $5 \mathrm{mCi}$, corrected for decay) for the remainder of the testing session. This bolus-plus-continuous-infusion method was performed as described in prior studies (Carson et al, 1997; Ito et al, 1998; Brody et al, 2006). Brain scans were acquired continuously for the next $50 \mathrm{~min}$.

At 1500 hours, participants were removed from the scanner with the infusion still running and had a 10-min break in an outdoor area adjacent to the PET scanning room, at which time they smoked either a regular or 
denicotinized cigarette (described below). A 3-h period of abstinence prior to the smoke break in scanning was chosen based on the finding that craving starts to peak at this time in smokers (Schuh and Stitzer, 1995), though it is acknowledged that DA release may be different if smokers are cigarette-deprived for longer periods of time. After the break, participants were quickly repositioned $(<1 \mathrm{~min})$ in the scanner using a preplaced mark on their forehead and a laser light from the scanner. Scanning then resumed for 30 min more.

Positron emission tomography scans were acquired with a GE Advance NXi PET tomograph (General Electronic Medical Systems, Milwaukee, WI) with 35 slices in 3-dimensional mode. ${ }^{11} \mathrm{C}$-raclopride was prepared by an established procedure (Farde et al, 1986; Ehrin et al, 1987). PET scans were acquired as 10 prebreak and six postbreak 5 -min frames. Attenuation correction scanning for both emission scans was performed using a 5-min transmission scan obtained with the germanium rotating rod source built into the GE scanner at the end of the scanning session.

An MRI scan of the brain was obtained within 1 week of the PET session with the following specifications: three-dimensional Fourier transform spoiled gradientrecalled acquisition with $\mathrm{TR}=30 \mathrm{~ms}, \mathrm{TE}=7 \mathrm{~ms}, 30^{\circ}$ angle, two acquisitions, $256 \times 192$ view matrix. The acquired volume was reconstructed as 90 contiguous, $1.5-\mathrm{mm}$ thick, transaxial slices.

\section{Cigarette Smoking during the Break in Scanning}

During the break in scanning, subjects smoked either one of their own cigarettes (mean $1.0 \pm 0.03 \mathrm{mg}$ nicotine, $14.2 \pm 0.5 \mathrm{mg}$ tar; $n=46$ ) or a standard denicotinized cigarette $(0.05 \mathrm{mg}$ nicotine, $10 \mathrm{mg}$ tar; Quest 3 brand; $n=16)$. Three-fourths of the participants were assigned to the regular cigarette group because this study was part of a larger treatment study that examined responses to regular cigarettes before and after treatment, and only those who smoked a regular cigarette were eligible for the larger study. To maintain a blind, all subjects gave one of their cigarettes to a research assistant who de-identified it by covering any brand markings. This de-identified regular brand cigarette or a de-identified denicotinized cigarette was then given to the study investigator (ALB, REO, or ZAM) who gave it to the participant to smoke during the break in scanning. Participants were observed continuously during the break. For the regular cigarette condition, subjects smoked one of the following cigarettes: Marlboro Regular $(n=9)$, Marlboro $100 \quad(n=2)$, Marlboro Light $(n=1)$, Camel Regular $(n=6)$, Camel Light $(n=3)$, Kool Regular $(n=3)$, Newport Regular $(n=6)$, Newport $100(n=5)$, Parliament Light $(n=9)$, or Benson and Hedges Regular $(n=2)$. Eleven of the cigarettes smoked for the regular cigarette condition were menthol cigarettes, whereas the denicotinized cigarettes were not menthol cigarettes.

To monitor smoking topography during scanning, cigarettes were smoked through a Clinical Research Support System device (Plowshare, Baltimore, MD). Although all standard recordings were obtained with this device, the primary measure of interest was total puff volume of the cigarette $(\mathrm{ml})$, which indicated the amount of each cigarette that was smoked.

\section{PET Image Analysis}

PET-to-MRI coregistration was performed using an automated image registration method (Woods et al, 1993) within MEDx 3.3 (Sensor Systems Inc., Sterling, VA). Prebreak (0-50 $\mathrm{min})$ and postbreak (60-90 $\mathrm{min})$ scans were coregistered to the MRI separately, and the individual 5-min time frames were coregistered to MRI scans using the transformation matrix parameters from the coregistration of the summed images.

Regions of interest (ROIs) were drawn on MRI and transferred onto the coregistered PET scan frames. ROI placement on each frame was verified by visual inspection by the region drawers (MRC and DS) and the PI. The ROI value used for statistical analysis was the volume-weighted decay-corrected mean of the left and right ventral caudate (VCD) ROIs (including NAc), consisting of three slices each, resulting in a single value for each 5-min frame of PET scanning (Brody et al, 2006). The cerebellum was drawn as a reference region. These regions were similar to those drawn in prior ${ }^{11} \mathrm{C}$-raclopride PET studies (Mawlawi et al, 2001; Martinez et al, 2003). Binding potential (BP) for $\mathrm{VCD} /$ NAc was calculated using the simplified reference tissue model (Lammertsma and Hume, 1996), with $\mathrm{BP}=B^{\prime}{ }_{\max } /$ $K_{\mathrm{d}}=C_{\mathrm{VCD} / \mathrm{NAc}} / C_{\text {cerebellum }}-1$, where $C$ is radioligand concentration. BP was determined for each 5-min PET frame, and mean BP values were compared between the frames before $(40-50 \mathrm{~min})$ and after $(60-90 \mathrm{~min})$ the break in scanning. These time frames are almost identical to those recommended as optimal for maximizing signal-tonoise ratio with the ${ }^{11} \mathrm{C}$-raclopride bolus-plus-continuousinfusion method (Watabe et al, 2000; Mawlawi et al, 2001). This method assumes $40 \mathrm{~min}$ for the radiotracer to reach an approximate steady state (Ito et al, 1998; Watabe et al, 2000; Mawlawi et al, 2001). It also assumes that intrasynaptic DA concentration will remain elevated throughout the 30-min postsmoking scan, as indicated by animal microdialysis and imaging studies cited above.

The single PET data variable for this study was percent change in $\mathrm{BP}$ from before to after smoking, defined as $100 \times\left(\mathrm{BP}_{\text {after smoking }}-\mathrm{BP}_{\text {before smoking }}\right) / \mathrm{BP}_{\text {before smoking. }} \mathrm{A}$ single $\mathrm{BP}$ measure was used here, based on prior reports demonstrating nearly identical $\mathrm{BP}$ changes for the left and right VCD/NAc (Brody et al, 2004, 2006), to minimize the risk of type I error.

\section{Statistical Analyses}

Demographic and rating scale data means ( \pm SEMs) were determined for the study groups. To verify baseline similarities in demographics between groups, unpaired Student's $t$-tests and a $\chi^{2}$ test (for gender) were performed for these variables. To determine similarities and differences in clinical responses to smoking the two cigarette types, unpaired Student's $t$-tests were performed between groups for changes in the three withdrawal symptom measures (craving/UTS, anxiety/Spielberger State-Trait Anxiety Index (STAI), and mood analog scale scores) from before to after smoking. To further characterize pre- to postsmoking changes in withdrawal symptoms, withingroup paired $t$-tests and examinations of means were also performed. 
For the PET data, changes in BP were compared between groups with an ANCOVA, with percent change in BP as the dependent measure, group (regular $v s$ denicotinized cigarette) as the between-subject factor, and age, gender, and total puff volume as covariates. Even though the groups did not have significant differences in these covariates (see below), these variables were included in the analysis, based on prior reports linking them with differences in DA system function (Wang et al, 1995; Pohjalainen et al, 1998; Kaasinen et al, 2000; Staley et al, 2001).

For the total group, correlation coefficients (controlling for group) were determined between percent change in $\mathrm{BP}$ and percent change in craving (UTS), state anxiety (STAI), and mood analog scores, to determine relationships between DA concentration change and effects of smoking on withdrawal symptoms. All statistical tests were performed with SPSS version 15.0 (SPSS, Chicago, IL).

\section{RESULTS}

\section{Clinical Results}

The total subject sample was middle-aged $(40.5 \pm 1.5$ years old), mostly male $(67.7 \%)$, smoked moderately $(24.2 \pm 0.9$ cigarettes/day) and for many years (22.5 \pm 1.5$)$, was moderately nicotine-dependent (FTND scores-6.4 \pm 0.2 ), and had moderate CO levels prior to the scanning session $(17.0 \pm 1.1$ p.p.m.). The groups assigned to smoking either a regular or a denicotinized cigarette did not differ significantly in any of these variables (Table 1) or on any of the subscales from the Shiffman-Jarvik Withdrawal scale (all unpaired Student's $t$-tests, NS).

The groups also did not differ in smoking topography. For the regular and denicotinized cigarette groups, total puff volume ( $886 \pm 44$ vs $941 \pm 81 \mathrm{ml}$, respectively), number of puffs (17.3 \pm 1.2 vs $19.3 \pm 1.8$, respectively), and average puff volume $(57.3 \pm 2.7$ vs $52.6 \pm 4.5 \mathrm{ml})$ were similar between groups (all unpaired Student's $t$-tests, NS).

From before to after smoking during scanning, the two groups did not differ significantly in craving or anxiety alleviation (both unpaired Student's $t$-tests, NS), but did differ in mood improvement. For craving, both groups had significant within-group reductions in craving/UTS score $(-76.0( \pm 3.5) \%$ for the regular cigarette group, paired Student's $t$-test, $p<0.0001$ and $-71.8( \pm 6.9) \%$ for the denicotinized cigarette group, paired Student's $t$-test, $p<0.0001$ ), indicating that craving was reduced significantly with both cigarette types. Similarly, both groups had comparable reductions in STAI anxiety scale scores $(-26.1( \pm 19.5) \%$ for the regular cigarette group and -21.7 $( \pm 16.3) \%$ for the denicotinized cigarette group). In contrast, the regular cigarette group had significantly more mood improvement $(+15.2( \pm 6.0) \%)$ than the denicotinized cigarette group $(-0.5( \pm 4.4) \%)$ (unpaired Student's $t$-test, $p=0.04)$.

\section{PET Results}

The group that smoked regular nicotine-containing cigarettes had a greater mean reduction in ${ }^{11} \mathrm{C}$-raclopride $\mathrm{BP}$ $(-8.4( \pm 1.5) \%)$ than the group that smoked denicotinized cigarettes $(-1.2( \pm 2.5) \%)$ (ANCOVA, d.f. $=1,57, \mathrm{~F}=6.8$, $p=0.01$ ) (Figure 1), indicating that those who smoked regular cigarettes had greater DA release.

For the total group, there was a significant negative correlation between change in ${ }^{11} \mathrm{C}$-raclopride $\mathrm{BP}$ and change in mood scale scores (correlation coefficient, $r=-0.33$, $p=0.01$ ) (Figure 2), indicating that greater DA release is associated with more mood improvement. There were no significant correlations between change in ${ }^{11} \mathrm{C}$-raclopride $\mathrm{BP}$ and change in UTS scale scores (correlation coefficient, $r=0.13$, NS) or STAI anxiety scale score (correlation coefficient, $r=-0.01$, NS).

Table I Demographic and Rating Scale Variables

\begin{tabular}{|c|c|c|c|c|}
\hline Variable & $\begin{array}{l}\text { Total group } \\
(n=62)\end{array}$ & $\begin{array}{l}\text { Regular nicotine } \\
\text { cigarette }(n=46)\end{array}$ & $\begin{array}{c}\text { De-nicotinized } \\
\text { cigarette }(n=16)\end{array}$ & $\begin{array}{l}\text { p-value (Nic vs } \\
\text { De-Nic groups) }\end{array}$ \\
\hline Age & $40.5( \pm 1.5)$ & $41.6( \pm 1.7)$ & $37.3( \pm 3.4)$ & NS \\
\hline Cigs/day & $24.2( \pm 0.9)$ & $24.9( \pm 1.0)$ & $22.3( \pm 1.6)$ & NS \\
\hline Years of smoking & $22.5( \pm 1.5)$ & $23.5( \pm 1.7)$ & $19.8( \pm 3.3)$ & NS \\
\hline HAM-D & $1.8( \pm 0.3)$ & $1.5( \pm 0.3)$ & $2.4( \pm 0.6)$ & NS \\
\hline HAM-A & $2.0( \pm 0.3)$ & $1.7( \pm 0.3)$ & $2.6( \pm 0.8)$ & NS \\
\hline CO level (p.p.m.) & $17.0( \pm 1.1)$ & $17.5( \pm 1.5)$ & $15.3( \pm 1.7)$ & NS \\
\hline \% Change in UTS (craving) with smoking & $-74.9( \pm 3.1)$ & $-76.0( \pm 3.5)$ & $-71.8( \pm 6.9)$ & NS \\
\hline \% Change in STAI with smoking & $-25.0( \pm 15.0)$ & $-26.1( \pm 19.5)$ & $-21.7( \pm 16.3)$ & NS \\
\hline
\end{tabular}

Values are stated as mean ( \pm SEM); $p$-values are for unpaired Student's $t$-tests between the groups that smoked either a regular nicotine or a denicotinized cigarette. Cig, cigarette; CO, exhaled carbon monoxide; De-Nic, denicotinized; FTND, Fagerström Test for Nicotine Dependence; HAM-A, Hamilton Anxiety Rating Scale; HAM-D, Hamilton Depression Rating Scale; Mood, mood analog rating scale score; Nic, nicotine; NS, nonsignificant; p.p.m., parts per million; STAI, Spielberger StateTrait Anxiety Index state anxiety questions total score; UTS, Urge to Smoke Scale; yrs, years. 


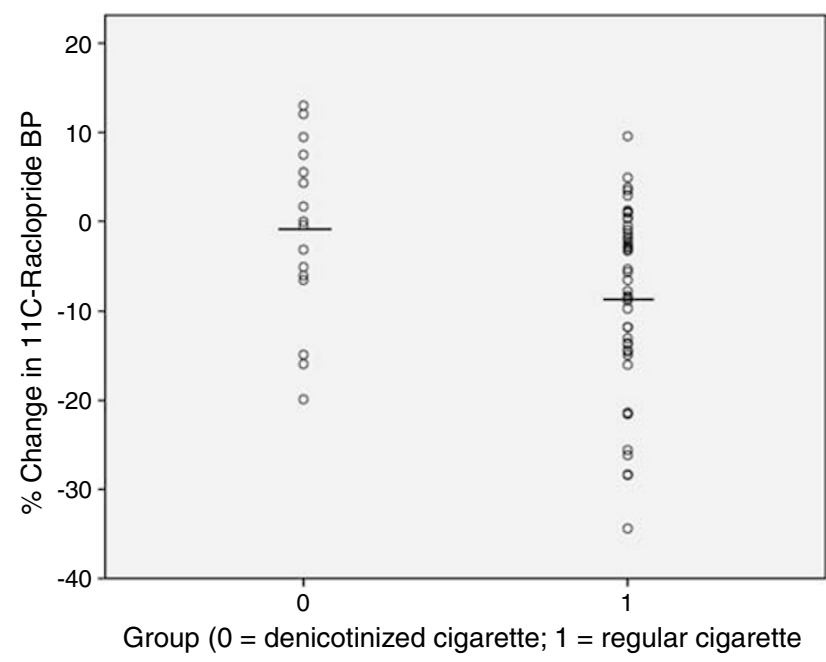

Figure I Scatterplot showing percent change in ${ }^{~}{ }^{C} \mathrm{C}$-raclopride binding potential (BP) for the group that smoked a denicotinized cigarette $(-1.2$ $( \pm 2.5) \% ; n=16)$ and the group that smoked a regular cigarette $(-8.4$ $( \pm 1.5) \% ; n=46)$. The group that smoked a denicotinized cigarette had less of a decrease in ${ }^{11} \mathrm{C}$-raclopride BP than the group that smoked a regular cigarette, indicating that nicotine inhalation is important for dopamine release.

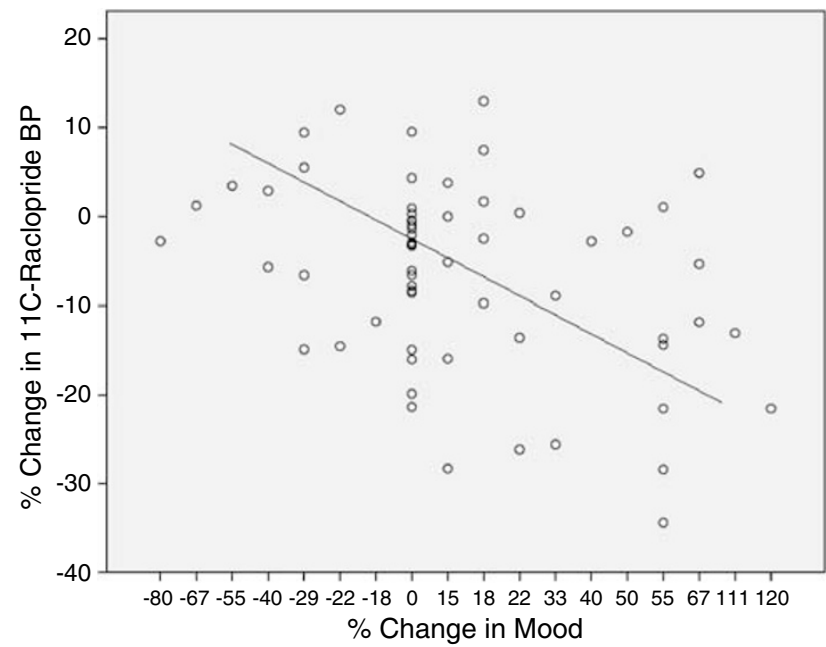

Figure 2 Scatterplot showing the negative correlation $(r=-0.33$, $p=0.0 \mathrm{I})$ between percent change in ${ }^{1} \mathrm{C}$-raclopride binding potential (BP) (an indirect measure of dopamine release) and percent change in mood analog rating scale score for the total group of tobacco-dependent smokers $(n=62)$.

\section{DISCUSSION}

In tobacco-dependent smokers, smoking regular $v s$ denicotinized cigarettes resulted in different patterns of both clinical and PET scanning findings. Smoking regular cigarettes resulted in significantly decreased craving and anxiety, improved mood, and DA release, whereas smoking denicotinized cigarettes resulted in decreased craving and anxiety, but no evidence of mood improvement or significant DA release. In addition, for the total group, there was an association between increasing DA release and mood improvement. These findings indicate that nicotine is necessary for smoking-induced DA release and support prior research demonstrating that denicotinized cigarettes relieve craving (Eid et al, 2005; Buchhalter et al, 2005), but that regular nicotine-containing cigarettes provide greater withdrawal relief (Pickworth et al, 1999; Buchhalter et al, 2001; Dallery et al, 2003; Donny et al, 2007) and more satisfaction (Butschky et al, 1995; Gross et al, 1997) and reward (Naqvi and Bechara, 2005; Donny et al, 2007) (measured here as mood improvement) than denicotinized cigarettes. The central finding of this study (smoking a regular cigarette resulting in greater displacement of ${ }^{11} \mathrm{C}$-raclopride BP than smoking a denicotinized cigarette) is consistent with animal microdialysis (Imperato et al, 1986; Di Chiara and Imperato, 1988; Benwell and Balfour, 1997; Janhunen and Ahtee, 2004) and imaging (Marenco et al, 2004; Scott et al, 2007; Takahashi et al, 2008) studies, which demonstrate the importance of nicotine administration for DA release. As expected, the $8.4 \%$ increase in DA concentration found here with smoking a regular cigarette was less than the $20-29 \%$ increase found with cocaine (Volkow et al, 1999; Park and Park, 2000) or the 19-31\% increase found with amphetamine (Carson et al, 1997; Hartvig et al, 1997; Drevets et al, 1999) administration in studies using similar methodology.

The finding of a reduction in craving with smoking a denicotinized cigarette also indicates that factors other than the rewarding effect of ventral striatal DA release are important for craving alleviation. Denicotinized cigarettes likely alleviate craving through either (1) the sensorimotor feel, taste, and smell of cigarettes (including some degree of airway sensory stimulation (Naqvi and Bechara, 2005)), (2) DA release in brain regions not studied here (such as the thalamus, hippocampus, and cerebral cortex (Christian et al, 2000; Slifstein et al, 2004)), (3) pharmacological effects of the thousands of constituents of tobacco smoke other than nicotine (Green and Rodgman, 1996), or (4) some combination of these factors. To clarify the issue of how denicotinized cigarettes exert their effect, studies of changes in brain activity (either blood flow or glucose metabolism) or other neurotransmitter systems in response to smoking these cigarettes would be informative. Though several groups have examined the smoking of denicotinized cigarettes as a control condition compared to smoking regular cigarettes during functional brain imaging (Rose et al, 2003, 2007; Zubieta et al, 2005), we are aware of only one study (cited below) that specifically examined the effects of smoking denicotinized cigarettes themselves on brain function.

Although (to our knowledge) no prior functional brain imaging studies have directly reported how denicotinized cigarettes alleviate craving, several functional brain imaging studies of cigarette craving itself (see Brody (2006) for review) point to brain circuitry that might mediate the diminished craving found in response to denicotinized cigarettes. When cigarette smokers are exposed to cigaretterelated (compared to neutral) cues, craving is found to correlate with regional glucose metabolism or perfusion in the prefrontal cortex, orbitofrontal cortex, anterior cingulate cortex, insula, sensorimotor cortex, and hippocampus (Brody et al, 2002; Zubieta et al, 2005; Rose et al, 2007). Changes in activity in these regions, which mediate brain functions possibly related to craving (eg, working and 
episodic memory, repetitive thoughts, arousal and sensorimotor function) could be responsible for the craving reduction seen with denicotinized cigarettes. The effects of smoking denicotinized cigarettes on craving may also be explained by their effect on neurotransmitter systems other than DA, as demonstrated in a recent study showing activation of mu-opioid receptor-mediated neurotransmission in the right anterior cingulate cortex from smoking denicotinized and regular nicotine cigarettes (Scott et al, 2007).

As for the other central finding of this study, the association between mood improvement and smoking-induced DA release is consistent with a large body of literature linking DA release with improved mood and pleasure. Most closely related to the present study are reports using ${ }^{11} \mathrm{C}$ raclopride $\mathrm{PET}$ that have linked $\mathrm{DA}$ release in the striatum with hedonic responses to cigarette smoking (Barrett et al, 2004) and with happiness following nicotine nasal spray administration (Montgomery et al, 2007). Similar relationships between DA release and mood improvement or reward have been demonstrated in response to amphetamine administration (Drevets et al, 2001; Oswald et al, 2005), monetary reward (Pappata et al, 2002; Zald et al, 2004), and eating a meal (Small et al, 2003). In addition, DA concentration has been found to decrease in subjects who experience decreased happiness/euphoria in response to catecholamine depletion (Verhoeff et al, 2003). The present findings reinforce the previously demonstrated relationship between DA concentration and mood, and point to the consistency of these findings across rewarding stimuli.

The strengths of the present study included a relatively large sample size for this line of research; well-matched groups with regard to demographic variables, cigarette usage, and absence of comorbidity; and a statistical method that minimized type I error by using a single BP value. The primary limitations of this study were the ones inherent to PET scanning with ${ }^{11} \mathrm{C}$-raclopride. Although this radiotracer is commonly used for the evaluation of DA release (Volkow et al, 1994; Carson et al, 1997; Schlaepfer et al, 1997; Ginovart et al, 2002; Brody et al, 2004, 2006; Marenco et al, 2004; Barrett et al, 2004; Scott et al, 2007) and generally demonstrates DA release when expected, the short half-life and variable pharmacokinetics of the radiotracer make its use logistically challenging for human studies, and can produce considerable variability within groups, as observed here (Figure 1). ${ }^{11} \mathrm{C}$-raclopride is also not a reliable radiotracer for examining competitive displacement in regions with low specific binding outside the striatum. For measuring non-striatal DA receptor levels, a radiotracer with very high affinity (such as ${ }^{18} \mathrm{~F}$-fallypride) might be more appropriate (for reviews see Siessmeier et al (2005); Elsinga et al (2006)). Another study limitation was the unequal sample size between the two groups (done for practical reasons), which resulted in greater power to detect change in the larger regular cigarette group compared to the smaller denicotinized cigarette group. Also, due to the fact that de-identified cigarettes of the subjects' own brand were used in this study, it is possible that varying cigarette composition (eg, regular cigarettes smoked here contained $14.2 \pm 0.5 \mathrm{mg}$ tar, whereas Quest cigarettes contained $10 \mathrm{mg}$ tar) or the fact that some subjects may have recognized their own brand of cigarettes could have affected study results.
Despite these limitations, this study did demonstrate that smoking regular nicotine cigarettes resulted in VCD/NAc $\mathrm{BP}$ change in the hypothesized direction, and this fact does lend confidence to the findings here, as does the expected significant correlation for the total group between VCD/ NAc BP reduction and mood improvement.

\section{ACKNOWLEDGEMENTS}

This study was supported by the Tobacco-Related Disease Research Program (ALB (11RT-0024 and 16RT-0098), the National Institute on Drug Abuse (ALB (R01s DA15059 and DA20872)), the Veterans Administration (ALB (Merit Review Type I Award)), the National Alliance for Research on Schizophrenia and Depression (ALB), and the Office of National Drug Control Policy (EDL (DABT63-00-C-1003)). We thank Josephine Ribe and Michael Clark for technical support in performing positron emission tomography and magnetic resonance imaging scans, respectively.

\section{CONFLICT OF INTEREST}

The author(s) declare that, except for income received from my primary employer, no financial support or compensation has been received from any individual or corporate entity over the past 3 years for research or professional service, and there are no personal financial holdings that could be perceived as constituting a potential conflict of interest.

\section{REFERENCES}

Barrett SP, Boileau I, Okker J, Pihl RO, Dagher A (2004). The hedonic response to cigarette smoking is proportional to dopamine release in the human striatum as measured by positron emission tomography and $[(11) \mathrm{C}]$ raclopride. Synapse 54: $65-71$.

Benwell ME, Balfour DJ (1997). Regional variation in the effects of nicotine on catecholamine overflow in rat brain. Eur J Pharmacol 325: 13-20.

Bowen R, Baetz M, Hawkes J, Bowen A (2006). Mood variability in anxiety disorders. J Affect Disord 91: 165-170.

Brody AL (2006). Functional brain imaging of tobacco use and dependence. J Psychiatr Res 40: 404-418.

Brody AL, Mandelkern MA, London ED, Childress AR, Bota RG, Ho ML et al (2002). Brain metabolic changes during cigarette craving. Arch Gen Psychiatry 59: 1162-1172.

Brody AL, Mandelkern MA, Olmstead RE, Scheibal D, Hahn E, Shiraga S et al (2006). Gene variants of brain dopamine pathways and smoking-induced dopamine release in the ventral caudate/nucleus accumbens. Arch Gen Psychiatry 63: 808-816.

Brody AL, Olmstead RE, London ED, Farahi J, Meyer JH, Grossman $P$ et al (2004). Smoking-induced ventral striatum dopamine release. Am J Psychiatry 161: 1211-1218.

Buchhalter AR, Acosta MC, Evans SE, Breland AB, Eissenberg T (2005). Tobacco abstinence symptom suppression: the role played by the smoking-related stimuli that are delivered by denicotinized cigarettes. Addiction 100: 550-559.

Buchhalter AR, Schrinel L, Eissenberg T (2001). Withdrawalsuppressing effects of a novel smoking system: comparison with own brand, not own brand, and de-nicotinized cigarettes. Nicotine Tob Res 3: 111-118.

Buckley TC, Holohan DR, Mozley SL, Walsh K, Kassel J (2007). The effect of nicotine and attention allocation on physiological and 
self-report measures of induced anxiety in PTSD: a double-blind placebo-controlled trial. Exp Clin Psychopharmacol 15: 154-164. Butschky MF, Bailey D, Henningfield JE, Pickworth WB (1995). Smoking without nicotine delivery decreases withdrawal in 12-hour abstinent smokers. Pharmacol Biochem Behav 50: 91-96.

Carson RE, Breier A, de Bartolomeis A, Saunders RC, Su TP, Schmall B et al (1997). Quantification of amphetamine-induced changes in $\left[{ }^{11} \mathrm{C}\right]$ raclopride binding with continuous infusion. J Cereb Blood Flow Metab 17: 437-447.

Christian BT, Narayanan TK, Shi B, Mukherjee J (2000). Quantitation of striatal and extrastriatal D-2 dopamine receptors using PET imaging of [(18)F] fallypride in nonhuman primates. Synapse 38: 71-79.

Corrigall WA, Franklin KB, Coen KM, Clarke PB (1992). The mesolimbic dopaminergic system is implicated in the reinforcing effects of nicotine. Psychopharmacology (Berl) 107: 285-289.

Cumming P, Rosa-Neto P, Watanabe H, Smith D, Bender D, Clarke PBS et al (2003). Effects of acute nicotine on hemodynamics and binding of [C-11] raclopride to dopamine D-2,D-3 receptors in pig brain. Neuroimage 19: 1127-1136.

Dallery J, Houtsmuller EJ, Pickworth WB, Stitzer ML (2003). Effects of cigarette nicotine content and smoking pace on subsequent craving and smoking. Psychopharmacology (Berl) 165: $172-180$.

Damsma G, Day J, Fibiger HC (1989). Lack of tolerance to nicotineinduced dopamine release in the nucleus accumbens. Eur $J$ Pharmacol 168: 363-368.

Dewey SL, Brodie JD, Gerasimov M, Horan B, Gardner EL, Ashby CRJ (1999). A pharmacologic strategy for the treatment of nicotine addiction. Synapse 31: 76-86.

Di Chiara G, Imperato A (1988). Drugs abused by humans preferentially increase synaptic dopamine concentrations in the mesolimbic system of freely moving rats. Proc Natl Acad Sci USA 85: 5274-5278.

Donny EC, Houtsmuller E, Stitzer ML (2007). Smoking in the absence of nicotine: behavioral, subjective and physiological effects over 11 days. Addiction 102: 324-334.

Drevets WC, Gautier C, Price JC, Kupfer DJ, Kinahan PE, Grace AA et al (2001). Amphetamine-induced dopamine release in human ventral striatum correlates with euphoria. Biol Psychiatry 49: 81-96.

Drevets WC, Price JC, Kupfer DJ, Kinahan PE, Lopresti B, Holt D et al (1999). PET measures of amphetamine-induced dopamine release in ventral versus dorsal striatum. Neuropsychopharmacology 21: 694-709.

Ehrin E, Gawell L, Hogberg T, Depaulis T, Strom P (1987). Synthesis of [Methoxy-H-3]- and [Methoxy-C-11]- labeled raclopride-specific dopamine-D2 receptor ligands. J Labelled Comp Radiopharm 24: 931-940.

Eid NC, Fant RV, Moolchan ET, Pickworth WB (2005). Placebo cigarettes in a spaced smoking paradigm. Pharmacol Biochem Behav 81: 158-164.

Elsinga PH, Hatano K, Ishiwata K (2006). PET tracers for imaging of the dopaminergic system. Curr Med Chem 13: 2139-2153.

Fagerström KO (1978). Measuring the degree of physical dependence to tobacco smoking with reference to individualization of treatment. Addict Behav 3: 235-241.

Farde L, Hall H, Ehrin E, Sedvall G (1986). Quantitative analysis of D2 dopamine receptor binding in the living human brain by PET. Science 231: 258-261.

First MB, Spitzer RL, Gibbon M, Williams JBW (1995). Structured Clinical Interview for DSM-IV Axis I Disorders-Patient Edition (SCID-I/P, version 2.0). American Psychiatric Press, Washington, DC.

Ginovart N, Hassoun W, Le Cavorsin M, Veyre L, Le Bars D, Leviel $\mathrm{V}$ (2002). Effects of amphetamine and evoked dopamine release on [C-11]raclopride binding in anesthetized cats. Neuropsychopharmacology 27: 72-84.
Green CR, Rodgman A (1996). The Tobacco Chemists' Research Conference; a half-century of advances in analytical methodology of tobacco and its products. Recent Advances in Tobacco Science 22: 131-304.

Gross J, Lee J, Stitzer ML (1997). Nicotine-containing versus de-nicotinized cigarettes: effects on craving and withdrawal. Pharmacol Biochem Behav 57: 159-165.

Hamilton M (1967). Development of a rating scale for primary depressive illness. Br J Soc Psychology 6: 278-296.

Hamilton M (1969). Diagnosis and rating of anxiety. $\mathrm{Br} J$ Psychiatry 3: 76-79.

Hartvig P, Torstenson R, Tedroff J, Watanabe Y, Fasth KJ, Bjurling $P$ et al (1997). Amphetamine effects on dopamine release and synthesis rate studied in the Rhesus monkey brain by positron emission tomography. J Neural Transm 104: 329-339.

Heatherton TF, Kozlowski LT, Frecker RC, Fagerström KO (1991). The Fagerström test for nicotine dependence: a revision of the Fagerström Tolerance Questionnaire. Br J Addict 86: 1119-1127.

Imperato A, Mulas A, Di Chiara G (1986). Nicotine preferentially stimulates dopamine release in the limbic system of freely moving rats. Eur J Pharmacol 132: 337-338.

Ito H, Hietala J, Blomqvist G, Halldin C, Farde L (1998). Comparison of the transient equilibrium and continuous infusion method for quantitative PET analysis of $\left[{ }^{11} \mathrm{C}\right]$ raclopride binding. J Cereb Blood Flow Metab 18: 941-950.

Janhunen S, Ahtee L (2004). Comparison of the effects of nicotine and epibatidine on the striatal extracellular dopamine. Eur $J$ Pharmacol 494: 167-177.

Jarvik ME, Caskey NH, Rose JE, Herskovic JE, Sadeghpour M (1989). Anxiolytic effects of smoking associated with four stressors. Addict Behav 14: 379-386.

Jarvik ME, Madsen DC, Olmstead RE, Iwamoto-Schaap PN, Elins JL, Benowitz NL (2000). Nicotine blood levels and subjective craving for cigarettes. Pharmacol Biochem Behav 66: 553-558.

Kaasinen V, Vilkman H, Hietala J, Nagren K, Helenius H, Olsson H et al (2000). Age-related dopamine D2/D3 receptor loss in extrastriatal regions of the human brain. Neurobiol Aging 21: 683-688.

Kassel JD, Shiffman S (1997). Attentional mediation of cigarette smoking's effect on anxiety. Health Psychol 16: 359-368.

Koob GF (1992). Drugs of abuse: anatomy, pharmacology and function of reward pathways. Trends Pharmacol Sci 13: 177-184.

Lammertsma AA, Hume SP (1996). Simplified reference tissue model for PET receptor studies. Neuroimage 4: 153-158.

Leshner AI, Koob GF (1999). Drugs of abuse and the brain. Proc Assoc Am Phys 111: 99-108.

Marenco S, Carson RE, Berman KF, Herscovitch P, Weinberger DR (2004). Nicotine-induced dopamine release in primates measured with [C-11] raclopride PET. Neuropsychopharmacology 29: 259-268.

Martinez D, Slifstein M, Broft A, Mawlawi O, Hwang DR, Huang Y et al (2003). Imaging human mesolimbic dopamine transmission with positron emission tomography. Part II: amphetamineinduced dopamine release in the functional subdivisions of the striatum. J Cereb Blood Flow Metab 23: 285-300.

Mawlawi O, Martinez D, Slifstein M, Broft A, Chatterjee R, Hwang $\mathrm{DR}$ et al (2001). Imaging human mesolimbic dopamine transmission with positron emission tomography: I. Accuracy and precision of $\mathrm{D}(2)$ receptor parameter measurements in ventral striatum. J Cereb Blood Flow Metab 21: 1034-1057.

Mitterschiffthaler MT, Fu CH, Dalton JA, Andrew CM, Williams SC (2007). A functional MRI study of happy and sad affective states induced by classical music. Hum Brain Mapp 28: 1150-1162.

Montgomery AJ, Lingford-Hughes AR, Egerton A, Nutt DJ, Grasby PM (2007). The effect of nicotine on striatal dopamine release in man: A [11C]raclopride PET study. Synapse 61: 637-645.

Naqvi NH, Bechara A (2005). The airway sensory impact of nicotine contributes to the conditioned reinforcing effects of 
individual puffs from cigarettes. Pharmacol Biochem Behav 81: 821-829.

Naqvi NH, Bechara A (2006). Skin conductance responses are elicited by the airway sensory effects of puffs from cigarettes. Int J Psychophysiol 61: 77-86.

Oswald LM, Wong DF, McCaul M, Zhou Y, Kuwabara H, Choi L et al (2005). Relationships among ventral striatal dopamine release, cortisol secretion, and subjective responses to amphetamine. Neuropsychopharmacology 30: 821-832.

Pappata S, Dehaene S, Poline JB, Gregoire MC, Jobert A, Delforge J et al (2002). In vivo detection of striatal dopamine release during reward: a PET study with [(11)C]raclopride and a single dynamic scan approach. Neuroimage 16: 1015-1027.

Park MH, Park EH (2000). Synaptic concentration of dopamine in rat striatal slices in relationship to $\left[{ }^{3} \mathrm{H}\right]$ raclopride binding to the dopamine D2 receptor. Arch Pharm Res 23: 360-366.

Pickworth WB, Fant RV, Nelson RA, Rohrer MS (1999). Pharmacodynamic effects of new de-nicotinized cigarettes. Nicotine Tob Res 1: 357-364.

Pohjalainen T, Rinne JO, Nagren K, Syvalahti E, Hietala J (1998). Sex differences in the striatal dopamine D2 receptor binding characteristics in vivo. Am J Psychiatry 155: 768-773.

Pomerleau OF, Turk DC, Fertig JB (1984). The effects of cigarette smoking on pain and anxiety. Addict Behav 9: 265-271.

Pontieri FE, Tanda G, Orzi F, Di Chiara G (1996). Effects of nicotine on the nucleus accumbens and similarity to those of addictive drugs. Nature 382: 255-257.

Rose JE, Behm FM, Salley AN, Bates JE, Coleman RE, Hawk TC et al (2007). Regional brain activity correlates of nicotine dependence. Neuropsychopharmacology 32: 2441-2452.

Rose JE, Behm FM, Westman EC, Mathew RJ, London ED, Hawk TC et al (2003). PET studies of the influences of nicotine on neural systems in cigarette smokers. Am J Psychiatry 160: 323-333.

Schlaepfer TE, Pearlson GD, Wong DF, Marenco S, Dannals RF (1997). PET study of competition between intravenous cocaine and $\left[{ }^{11} \mathrm{C}\right]$ raclopride at dopamine receptors in human subjects. Am J Psychiatry 154: 1209-1213.

Schuh KJ, Stitzer ML (1995). Desire to smoke during spaced smoking intervals. Psychopharmacology (Berl) 120: 289-295.

Schuh LM, Stamat HM, Downey KK, Schuh KJ (2001). Subjective and discriminative stimulus effects of two de-nicotinized cigarettes with different tar yields. Nicotine Tob Res 3: 77-83.

Scott DJ, Domino EF, Heitzeg MM, Koeppe RA, Ni L, Guthrie S et al (2007). Smoking modulation of mu-opioid and dopamine D2 receptor-mediated neurotransmission in humans. Neuropsychopharmacology 32: 450-457.

Shiffman SM, Jarvik ME (1976). Smoking withdrawal symptoms in two weeks of abstinence. Psychopharmacology (Berl) 50: 35-39.

Siessmeier T, Zhou Y, Buchholz HG, Landvogt C, Vernaleken I, Piel $\mathrm{M}$ et al (2005). Parametric mapping of binding in human brain of D2 receptor ligands of different affinities. J Nucl Med 46: 964-972.

Slifstein M, Narendran R, Hwang DR, Sudo Y, Talbot PS, Huang Y et al (2004). Effect of amphetamine on [(18)F] fallypride in vivo binding to $\mathrm{D}(2)$ receptors in striatal and extrastriatal regions of the primate brain: Single bolus and bolus plus constant infusion studies. Synapse 54: 46-63.

Small DM, Jones-Gotman M, Dagher A (2003). Feeding-induced dopamine release in dorsal striatum correlates with meal pleasantness ratings in healthy human volunteers. Neuroimage 19: $1709-1715$.

Spielberger C (1983). Manual for the State-Trait Anxiety Inventory. Consulting Psychologists Press: Palo Alto, CA.

Staley JK, Krishnan-Sarin S, Zoghbi S, Tamagnan G, Fujita M, Seibyl JP et al (2001). Sex differences in [123I]beta-CIT SPECT measures of dopamine and serotonin transporter availability in healthy smokers and nonsmokers. Synapse 41: 275-284.

Sziraki I, Lipovac MN, Hashim A, Sershen H, Allen D, Cooper T et al (2001). Differences in nicotine-induced dopamine release and nicotine pharmacokinetics between Lewis and Fischer 344 rats. Neurochem Res 26: 609-617.

Takahashi H, Fujimura Y, Hayashi M, Takano H, Kato M, Okubo Y et al (2008). Enhanced dopamine release by nicotine in cigarette smokers: a double-blind, randomized, placebo-controlled pilot study. Int J Neuropsychopharmacol 11: 413-417.

Tsukada H, Miyasato K, Kakiuchi T, Nishiyama S, Harada N, Domino EF (2002). Comparative effects of methamphetamine and nicotine on the striatal [C-11] raclopride binding in unanesthetized monkeys. Synapse 45: 207-212.

Verhoeff NP, Christensen BK, Hussey D, Lee M, Papatheodorou G, Kopala L et al (2003). Effects of catecholamine depletion on D2 receptor binding, mood, and attentiveness in humans: a replication study. Pharmacol Biochem Behav 74: 425-432.

Volkow ND, Fowler JS, Gatley SJ, Dewey SL, Wang GJ, Logan J et al (1999). Comparable changes in synaptic dopamine induced by methylphenidate and by cocaine in the baboon brain. Synapse 31: 59-66.

Volkow ND, Wang GJ, Fowler JS, Logan J, Schlyer D, Hitzemann R et al (1994). Imaging endogenous dopamine competition with [11C] raclopride in the human brain. Synapse 16: 255-262.

Wang GJ, Volkow ND, Logan J, Fowler JS, Schlyer D, MacGregor RR et al (1995). Evaluation of age-related changes in serotonin 5-HT2 and dopamine D2 receptor availability in healthy human subjects. Life Sci 56: 249-253.

Watabe H, Endres CJ, Breier A, Schmall B, Eckelman WC, Carson RE (2000). Measurement of dopamine release with continuous infusion of $\left[{ }^{11} \mathrm{C}\right]$ raclopride: optimization and signal-to-noise considerations. J Nucl Med 41: 522-530.

Wild B, Erb M, Bartels M (2001). Are emotions contagious? Evoked emotions while viewing emotionally expressive faces: quality, quantity, time course and gender differences. Psychiatry Res 102: 109-124.

Woods RP, Mazziotta JC, Cherry SR (1993). MRI-PET registration with automated algorithm. J Comput Assist Tomogr 17: 536-546.

Zald DH, Boileau I, El-Dearedy W, Gunn R, McGlone F, Dichter GS et al (2004). Dopamine transmission in the human striatum during monetary reward tasks. J Neurosci 24: 4105-4112.

Zubieta JK, Heitzeg MM, Xu Y, Koeppe RA, Ni L, Guthrie S et al (2005). Regional cerebral blood flow responses to smoking in tobacco smokers after overnight abstinence. Am J Psychiatry 162: $567-577$. 